\begin{tabular}{lr}
\hline \multicolumn{1}{c}{ D Y N A M I C E C O N O M E T R I C } & M O D E L S \\
DOI: http://dx.doi.org/10.12775/DEM.2018.005 & Vol. 18 (2018) 81-97 \\
\hline $\begin{array}{l}\text { Submitted November 25, } 2018 \\
\text { Accepted December 17, } 2018\end{array}$ & ISSN (online) 2450-7067 \\
ISSN (print) 1234-3862
\end{tabular}

\title{
Dominik Krężołek*
}

\section{Testing Day of the Week Effect on Precious Metals Market}

\begin{abstract}
A b s t r a c t. Market efficiency assumes that asset prices should be characterized by randomness and unpredictability, so that potential market participants are not able to generate aboveaverage profits. This means that there should be no seasonal phenomenon in time series, which clearly projects a certain pattern of behavior of financial assets. The paper is an attempt to verify some specific seasonal effect called "the day of the week" on the precious metals market using AR-GARCH(APARCH) models. The selection of this area is not accidental. Precious metals are an alternative to classic capital investments, especially in the case of financial and economic crises. In addition, the literature shows a gap in this area in terms of dynamics analysis on commodity markets, if compared to capital market. The results are not unambiguous and the effect of seasonality was observed for the volatility of gold returns in the entire period and in the period of upward trend (positive returns on Fridays). The returns of palladium suffer from seasonality during entire period and in the period of upward trend (positive returns on Fridays, negative on Mondays, Tuesdays and Thursdays). Moreover, it was observed that the ARAPARCH models is more appropriate when taking into account the heavy-tail distributions of residuals.
\end{abstract}

K e y w o r d s: APARCH model; day of the week; GARCH model; precious metals; time series.

J E L Classification: C22; G01; G14.

\section{Introduction}

In the theory of economics and finance the term "market efficiency" assumes that at any time asset prices accurately reflect the full available

${ }^{*}$ Correspondence to: Dominik Krężołek, Department of Demography and Economic Statistics, University of Economics in Katowice, 1 Maja 50 Street, 40-287 Katowice, Poland, e-mail: dominik.krezolek@ue.katowice.pl.

(C) 2018 Nicolaus Copernicus University. All rights reserved. http://www.dem.umk.pl/dem 
information about them. The term "effective market" first appeared in Bachelier's paper (Bachelier, 1900), but it did not get much interest from the scientific community. In the second half of XX century, the American economist Eugene Fama discussed this problem and considered so-called efficientmarket hypothesis (Fama, 1970) in the context of weak, semi-strong and strong efficiency. According to his perception, week market efficiency assumes that currently realized prices reflect the historical data and it is not possible to forecast future level of prices from historical data. The hypothesis of semi-strong efficiency proclaims that current asset prices reflect all public information available, including historical data, reports and any available economic forecasts The last one - strong market efficiency assumes the existence of full public and non-public information about assets considered, and this information is available for everyone at any given time. This hypothesis is the most restrictive and means that all kind of analyzes carried out on financial market, including technical and fundamental analysis, would be unnecessary, as it wouldn't be possible to obtain above-average profits based on full available information.

As one can see, the efficiency of the market doesn't go hand in hand with the main goal of investment activity, which is multiplying assets. In this paper some selected calendar anomalies are considered. As "calendar anomalies" we define statistically significant differences in levels of prices/returns for a given financial assets depending on the adopted period.

\section{Calendar Effects on Financial Market - Literature Review}

When introducing the problem of calendar anomalies, it is worth to define those which are most often considered in the analysis of financial market data. One can mention here, among others, such anomalies like effect of the month in the year, effect of the turn of the month, holidays effect, effect of the day of the week or even the effect of the hour on the day. Each of these anomalies undermines the efficiency of the market and is the topic of analyzes in scientific communities around the world.

The effect of the month in the year reflects significant differences in the average values of returns of financial assets in particular months of the year. The most popular anomalies in this group are the effect of January, May or September. In the first case, it was observed that average level of returns in January is significantly higher than these observed in other months. In turn, May and September effects are associated with semi-low level of returns.

The turn of the month is related by the phenomenon when we can observe the average higher prices (returns) at the end of month if compared to their values in the first days of the following month. This situation may result from the allocation of funds obtained in the middle of the month in investment funds 
(Fiszeder et al., 2013). In the case of the holidays effect, which s related to the effect of the month, increases of financial assets returns are observed before holidays, while declines in the period just after holidays. A similar relationship can be observed in the case of holiday periods, when no trading sessions are held.

If the anomalies during the week are observed, it means so-called the day of the week effect. It can be described as significant differences of the level of returns on financial assets depending on the day of the week (most often fiveday week is considered, however, there are some assets listed in the seven-day trading system (e.g. the returns of electricity prices (Ganczarek-Gamrot, 2013))

The phenomenon of volatility in daily returns during a week is the problem analyzed not only by practitioners but also by scientists. K. French (1980), while analyzing the U.S. market, observed high, statistically significant volatility in stocks returns. In his research he showed that the returns realized on Friday were significantly higher comparing to the other days, while the returns realized on Monday - respectively lower, negative on average. Other researchers also came to similar conclusions, including Lakonishok and Smidt (1988). Jaffe and Westerfield analyzed the capital markets in Japan and Australia and they observed average negative, statistically significantly different returns on Tuesdays comparing with other days of the week (Jaffe et al., 1985). On the Polish capital market that kind of research was conducted, among others, by Szyszka (1999). In his research based on data from the Warsaw Stock Exchange, he observed positive returns on Mondays and negative on Tuesdays. Similar results were obtained by Landmesser (2006), Witkowska, Kompa (2007). Additionally, they pointed out positive returns on Fridays. A slightly different study was conducted by a Fiszeder and Kożuchowska (2013). They studied anomalies of indices WIG and WIG20. The obtained results indicating the turn of the month effect, no seasonal and mild disturbances during the week.

When analyzing the precious metals market, there is few papers in which the issue of seasonality in the context of anomalies would be discussed. Ma (1986) in his research showed positive returns on Fridays and negative Mondays for gold. More recent studies, taking into account the last 30 years, result in slightly different conclusions. Aksoy (2013) observed negative returns form gold on Mondays and Fridays on Istanbul Gold Exchange. Arora et al. (2013) discovered positive, statistically significant returns on Tuesdays and Fridays. In research of Kohli (2012) the positive returns on Fridays and Wednesdays for gold and positive returns on Wednesdays for silver were detected. 
The use of appropriate statistical tools allows to create models that adequately reflect such kind of seasonality. The results will allow to effectively forecast level of returns or prices in economic (financial) time series.

\section{Methodology and Statistical Tools}

Based on the regressive approach, the model describing the seasonality of the returns, taking into account different days of the week, can be written in the following way:

$$
r_{t}=\sum_{k=1}^{5} \omega_{k} d_{k t}+\varepsilon_{t}
$$

where $r_{t}$ is the return on the asset at the moment $t$, while $d_{k t}$ is the binary variable representing the $k-t h$ day of the week.

To describe volatility on financial time series one of the most popular model is the one proposed by Engle (1982) - the ARCH model extended by Bollerslev (1986) into the GARCH model. One of the main assumptions of $\mathrm{ARCH}$ model is the time-independence of returns. The expected return and variance can be described by historical information and presented by formulas:

$$
\begin{aligned}
& \mu_{t}=E\left(r_{t} \mid I_{t-1}\right) \\
& \sigma_{t}^{2}=\sigma^{2}\left(r_{t} \mid I_{t-1}\right)
\end{aligned}
$$

where $\mu_{t}$ and $\sigma_{t}^{2}$ define conditional expected return and conditional variance in time $t$, whereas $I_{t-1}$ defines the information set available in time $t-1$. The $\operatorname{GARCH}(m, s)$ model of Bollerslev can be described using formulas (Tsay, 2005):

$$
\begin{aligned}
& r_{t}-\mu_{t}=a_{t}=\sigma_{t} \varepsilon_{t} \\
& \sigma_{t}^{2}=\alpha_{0}+\sum_{i=1}^{m} \alpha_{i} a_{t-i}^{2}+\sum_{j=1}^{s} \beta_{j} \sigma_{t-j}^{2}
\end{aligned}
$$

where $\alpha_{0}>0 . \alpha_{i} \geq 0$ for $i>0 . \beta_{j} \geq 0$ and $\sum_{i=1}^{\max (m, s)}\left(\alpha_{i}+\beta_{i}\right)<1$.

The family of GARCH models is comprehensively described in the literature where many interesting properties are highlighted, i.e. the ability of modelling heavy-tailed distribution. The main disadvantage of GARCH models is that do not describe asymmetry observed in the and neither both leverage and long-memory effects. To solve this problems Ding et al. (1993) proposed new family of models describing these stylized facts observed in financial time series - the class of APARCH (Asymmetric Power ARCH) models. Mathematical formula takes a form (Karanasos et al., 2006):

$$
\sigma_{t}^{\delta}=\alpha_{0}+\sum_{i=1}^{q} \alpha_{i}\left(\left|a_{t-i}\right|-\gamma_{i} a_{t-i}\right)^{\delta}+\sum_{j=1}^{p} \beta_{j} \sigma_{t-j}^{\delta}
$$


where $-1<\gamma_{i}<1$ and $\delta>0$. The parameter $\gamma$ describes the leverage effect. A positive value of $\gamma$ means that past negative shocks have a deeper impact on current conditional volatility than past positive shocks. A negative value means the opposite (negative value means that positive information has stronger impact than the negative information on the price volatility). Moreover, ARCH and GARCH models are special cases of APARCH $(\mathrm{ARCH}(q)$ for $\delta=2, \gamma_{i}=0 . \beta_{i}=0 . \operatorname{GARCH}(p, q)$ for $\left.\delta=2, \gamma_{i}=0\right)$. The estimation of unknown parameters of APARCH model is usually conducted using the MLE.

In this paper, to model volatility, we used the combination of two models: $\mathrm{AR}$ and GARCH (APARCH). The first one represents conditional expected return (with a part related to the seasonality effect) whereas the second one is related to conditional variance. Therefore, we can write the formulas for $\operatorname{AR}(m)-\operatorname{GARCH}(p, q)$ and $\operatorname{AR}(m)-\operatorname{APARCH}(p, q)$ models as below:

- AR-GARCH:

$$
\begin{aligned}
& r_{t}-\mu-\sum_{i=1}^{m} \varphi_{i} r_{t-i}-\sum_{k=1}^{5} \omega_{k} d_{k t}=a_{t}=\sigma_{t} \varepsilon_{t} \\
& \sigma_{t}^{2}=\alpha_{0}+\sum_{i=1}^{q} \alpha_{i} a_{t-i}^{2}+\sum_{j=1}^{p} \beta_{j} \sigma_{t-j}^{2}
\end{aligned}
$$

- AR-APARCH:

$$
\begin{aligned}
& r_{t}-\mu-\sum_{i=1}^{m} \varphi_{i} r_{t-i}-\sum_{k=1}^{5} \omega_{k} d_{k t}=a_{t}=\sigma_{t} \varepsilon_{t} \\
& \sigma_{t}^{\delta}=\alpha_{0}+\sum_{i=1}^{q} \alpha_{i}\left(\left|a_{t-i}\right|-\gamma_{i} a_{t-i}\right)^{\delta}+\sum_{j=1}^{p} \beta_{j} \sigma_{t-j}^{\delta}
\end{aligned}
$$

where $\varphi_{i}, i=1, \ldots, m$ stands form autoregressive model's parameters and $d_{k t}$ is dummy variable representing the $k-t h$ day of the week in the equation of conditional expected return. To avoid the effect of collinearity between intercept and dummy variables representing $k-t h$ day of the week in equations (7) and (9) while estimating unknown parameters, one of the dummy variables has to be omitted and its missing value should be assessed using appropriates identities (Fiszeder et al., 2013)

From the literature we know that the correct financial time series analysis requires to examine simultaneously the conditional mean, conditional variance and standardised residuals described by the proper probability function. The most popular distributions describing residuals $\varepsilon_{t}$ are conditional standard normal, t-Student or Generalized Error Distribution (GED) (Piontek, 2002). This t-Student and GED distributions have gained popularity because of some specific features as high level of kurtosis or heavy tails (similar to distributions based on Extreme Value Theory). The conditional standard normal, t-Student and GED distributions for residuals can be described in terms of probability distribution functions as follow: 


$$
\begin{aligned}
& f_{N}\left(\varepsilon_{t}, \sigma_{t}^{2} ; \theta\right)=\frac{1}{\sigma_{t} \sqrt{2 \pi}} \exp \left\{-\frac{\varepsilon_{t}^{2}}{2 \sigma_{t}^{2}}\right\} \\
& f_{\text {Stud }}\left(\varepsilon_{t}, \sigma_{t}^{2} ; \theta\right)=\frac{\Gamma\left(\frac{v+1}{2}\right)}{\sigma_{\mathrm{t}} \Gamma\left(\frac{v}{2}\right) \sqrt{\pi(v-2)}}\left(1+\frac{\varepsilon_{t}^{2}}{(v-2) \sigma_{t}^{2}}\right)^{\frac{v+1}{2}} \\
& f_{G E D}\left(\varepsilon_{t}, \sigma_{t}^{2} ; \theta\right)=2^{-\frac{v+1}{v}} \frac{v}{\sigma_{t} \sqrt{\frac{\Gamma\left(v^{-1}\right)}{\Gamma\left(3 v^{-1}\right)} 2^{-\frac{2}{v}} \Gamma\left(v^{-1}\right)}} \exp \left\{-\frac{1}{2} \mid \frac{\varepsilon_{t}}{\left.\sigma_{t} \sqrt{\frac{\Gamma\left(v^{-1}\right)}{\Gamma\left(3 v^{-1}\right)} 2^{-\frac{2}{v}}}\right|^{v}}\right\}
\end{aligned}
$$

where $\left\{\varepsilon_{t}\right\}$ stands for the sequence of iid random variables, $\sigma_{t}^{2}$ is the conditional variance of the process, $\theta$ is the vector of estimated parameters, $v$ is the number of degrees of freedom, and $\Gamma(k)=\int_{0}^{+\infty} x^{k-1} e^{-1} d x$ is the gamma function with parameter $k$.

If the model is fitted, the next step is to assess the goodness of this fitting. We can use the information criteria of: Akaike (AIC), Schwarz (BIC) and Hannan-Quinn (HQC). The values of these criteria are calculated using formulas as below:

$$
\begin{aligned}
& A I C=-2 \ln [\operatorname{LLF}(\hat{\theta})]+2 k \\
& B I C=-2 \ln [\operatorname{LLF}(\hat{\theta})]+k \ln (n) \\
& H Q C=-2 \ln [\operatorname{LLF}(\hat{\theta})]+2 k \ln [\ln (n)]
\end{aligned}
$$

where $\operatorname{LLF}(\hat{\theta})$ is the $\log$-likelihood function of the parameters vector $\hat{\theta}, k$ is the number of estimated parameters and $n$ is the number of observations. The final selection is based on the values of one the information criteria: the lower values, the better the model.

\section{Empirical Analysis on Precious Metals Market}

The precious metal market is part of the commodity market - an alternative area for classical financial investments. Its popularity has increased due to the opportunities that offers to investors. The main reason for investing funds on the metals market is to hedge against financial crises. The empirical research shows a negative correlation of precious metals prices and stock exchange indices (Draper et al., 2010). Precious metals have a wide range of applications. They are used in many industries (e.g. automotive, space industry etc.), medicine, biology, jewelry, cosmetology and even in gastronomy. It is difficult to synthetically indicate the exact use of precious metals, but it is worth mentioning about their psychological aspects: precious metals are 
usually associated with wealth and economic stability, especially during crisis. Therefore, the analysis of that kind of assets is justified.

The hypothesis says that precious metals market is characterized by calendar anomalies (in this case: the day of the week effect). The daily log-returns for gold, silver, platinum and palladium from the London Metal Exchange are considered. The period of analysis is January 2000 - December 2016, finally divided into two sub-periods: a period of upward trend (January 2000 - August 2011) and a downward trend respectively (September 2011 - December 2016). A comparison of the volatility of gold and silver prices with the volatility of global stock indices seems worth commenting. For example, the S\&P500 and NASDAQ COMPOSITE quotes together with gold and silver are presented in the same time period (Fig. 1).
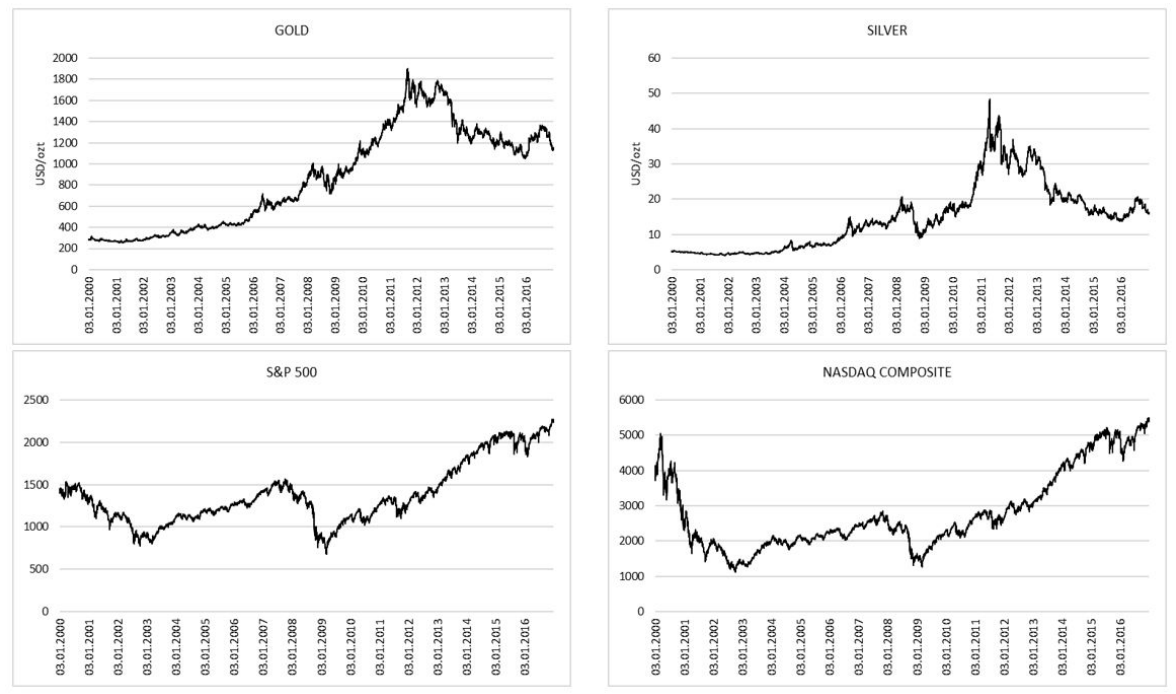

Figure 1. Quotations of gold (top-left), silver (top-right), S\&P500 (bottom-left) and NASDAQ COMPOSITE (bottom-right) - all period

It is clearly visible that the upward trend after the crisis on the financial markets (2007-2009) coincides with a significant downward trend observed for gold/silver. In addition, when considering the period of the crisis, it is worth mentioning that then were recorded the highest gold prices comparing to the entire period. The driving force behind this is the withdrawal of funds from the capital market and allocation in an alternative way (e.g. on metals market) in order to hedge against price drops.

The main goal of the analysis is the volatility of returns observed within precious metals. Based on the data from the LME, daily log-returns were 
estimated. The time series of the analyzed data during entire period are presented in figure 2.
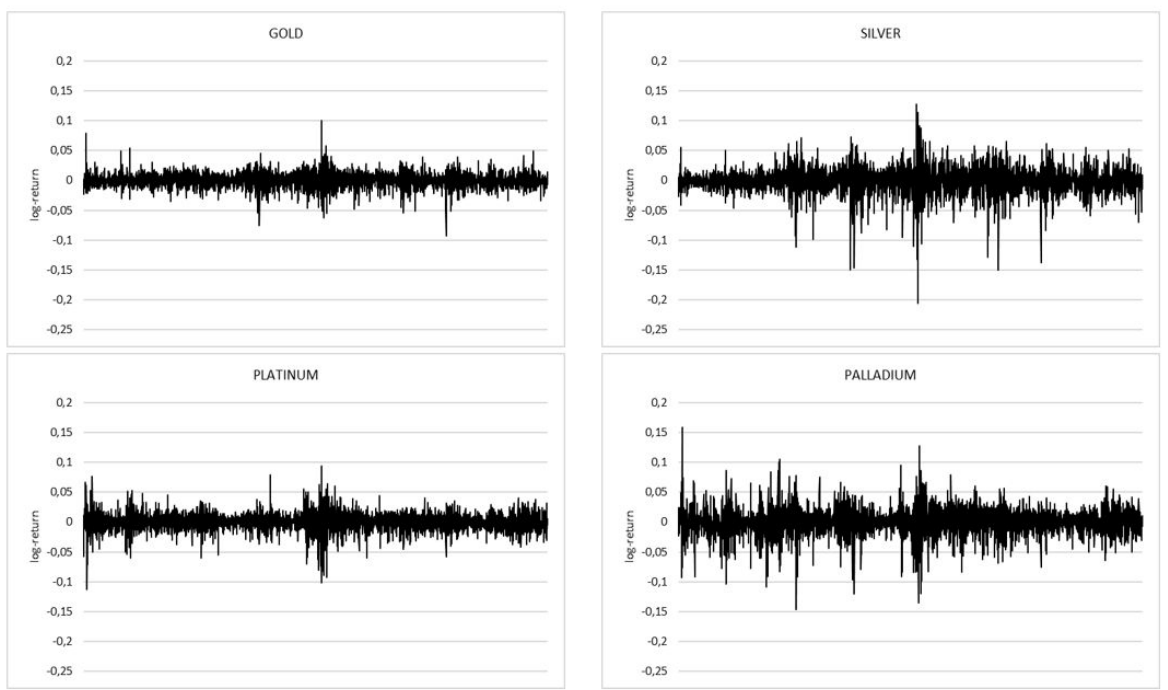

Figure 2. Log-returns of gold (top-left), silver (top-right), platinum (bottom-left) and palladium (bottom-right) - all period

Table 1. Average levels of returns for days of the week

\begin{tabular}{cccccc}
\hline \multirow{2}{*}{ ALL } & \multicolumn{5}{c}{ ENTIRE PERIOD } \\
\cline { 2 - 6 } & MONDAY & TUESDAY & WEDNESDAY & THURSDAY & FRIDAY \\
\hline GOLD & 0.00006 & -0.00011 & -0.00005 & 0.00018 & 0.00151 \\
SILVER & 0.00021 & -0.00006 & 0.00026 & -0.00049 & 0.00134 \\
PALLADIUM & -0.00071 & 0.00015 & -0.00013 & -0.00028 & 0.00147 \\
PLATINUM & 0.00016 & -0.00029 & 0.00009 & 0.00015 & 0.00074 \\
\hline PERIOD 1 & \multicolumn{5}{c}{ PERIOD OF UPWARD TREND } \\
\cline { 2 - 6 } & MONDAY & TUESDAY & WEDNESDAY & THURSDAY & FRIDAY \\
\hline GOLD & 0.00038 & 0.00016 & 0.00045 & 0.00021 & 0.00193 \\
SILVER & 0.00064 & 0.00014 & 0.00111 & -0.00042 & 0.00202 \\
PALLADIUM & -0.00044 & 0.00023 & 0.00027 & -0.00068 & 0.00155 \\
PLATINUM & 0.00082 & -0.00034 & 0.00049 & 0.00031 & 0.00118 \\
\hline PERIOD 2 & PONDAY & TUESDAY & WEDNESDAY & THURSDAY & FRIDAY \\
\cline { 2 - 6 } & -0.00064 & -0.00071 & -0.00114 & 0.00012 & 0.00060 \\
GOLD & -0.00073 & -0.00051 & -0.00163 & -0.00062 & -0.00014 \\
SILVER & -0.00130 & -0.00004 & -0.00101 & 0.00059 & 0.00129 \\
PALLADIUM & -0.00126 & -0.00019 & -0.00080 & -0.00019 & -0.00023 \\
PLATINUM & -0.50
\end{tabular}

The highest volatility was observed for SILVER and palladium return rates. Data clusters and grouping of variances are clearly visible. In addition, all figures show a significant increase in the level of volatility corresponding to the beginning of the upward trend on global economy. In table 1 the average 
levels of returns for every day of the week for entire period and all subperiods are shown.

The results show that during entire period the average positive returns on Fridays were observed, regardless of the type of metal. Gold realized negative returns on Tuesdays and Wednesdays, silver on Tuesdays and Thursdays, palladium on Mondays, Wednesdays and Thursdays, while platinum only on Tuesdays. Positive returns were observed for other days. During the upward trend, the average returns on Fridays were much higher comparing to the other days of the week. All metals generated on average positive returns and the differences determined by the day of the week are clearly visible. Similar conclusions can be drawn in the case of a downward trend, with the average negative returns observed on all days. Nevertheless, we can still see the diversity due to the day of the week. In the case of gold and silver, the lowest returns were observed on Wednesdays, while for platinum and palladium on Mondays. Summarizing this results we can suppose that the day of the week is observed on metals market.

Table 2. AR-GARCH and AR-APARCH models - gold - entire period

\begin{tabular}{|c|c|c|c|c|c|c|}
\hline Parameter & AR(1)-GARCH(1,1)-N & $p$-value & AR(1)-GARCH(1,1)-S & $\mathrm{p}$-value & AR(1)-GARCH(1,1)-GED & $p$-value \\
\hline$\varphi_{0}$ & 0.00158 & $0.000^{* * *}$ & 0.00132 & $0.000^{* * *}$ & 0.00124 & $0.001^{* * *}$ \\
\hline$\varphi_{1}$ & -0.00111 & 0.950 & -0.02239 & $0.097^{*}$ & -0.02077 & 0.192 \\
\hline$\omega_{M o n}$ & -0.00164 & $0.001^{* * *}$ & -0.00109 & $0.005^{* * *}$ & -0.00106 & $0.035^{* *}$ \\
\hline$\omega_{\text {Tue }}$ & -0.00159 & $0.002^{* * *}$ & -0.00129 & $0.002^{* \star *}$ & -0.00113 & $0.034^{* *}$ \\
\hline$\omega_{W e d}$ & -0.00169 & $0.001^{* * *}$ & -0.00112 & $0.007^{* * *}$ & -0.00100 & $0.042^{* *}$ \\
\hline$\omega_{\text {Thur }}$ & -0.00145 & $0.007^{* * *}$ & -0.00121 & $0.005^{\star * *}$ & -0.00118 & $0.017^{\star *}$ \\
\hline$\omega_{F r i}$ & 0.00158 & $0.000^{* * *}$ & 0.00132 & $0.000^{* * *}$ & 0.00124 & $0.000^{* * *}$ \\
\hline$\alpha_{0}$ & 0.00000 & $0.031^{* *}$ & 0.00000 & $0.001^{* * *}$ & 0.00000 & $0.003^{* * *}$ \\
\hline$\alpha_{1}$ & 0.03952 & $0.002^{* * *}$ & 0.04504 & $0.000^{* * *}$ & 0.04256 & $0.000^{* * *}$ \\
\hline$\beta_{1}$ & 0.94563 & $0.000^{* * *}$ & 0.94754 & $0.000^{* * *}$ & 0.94636 & $0.000^{* * *}$ \\
\hline$v$ & - & - & 4.71052 & $0.000^{* * *}$ & 1.18248 & $0.000^{* * *}$ \\
\hline Parameter & AR(1)-APARCH(1,1)-N & $p$-value & AR(1)-APARCH(1,1)-S & p-value & AR(1)-APARCH(1,1)-GED & $\mathrm{p}$-value \\
\hline$\varphi_{0}$ & 0.00164 & $0.000^{\star * *}$ & 0.00138 & $0.000^{\star * *}$ & 0.00130 & $0.000^{\star \star \star}$ \\
\hline$\varphi_{1}$ & -0.00220 & 0.357 & -0.02688 & $0.057^{*}$ & -0.02415 & $0.000^{* * *}$ \\
\hline$\omega_{M o n}$ & -0.00164 & $0.001^{* * *}$ & -0.00112 & $0.004^{* * *}$ & -0.00111 & $0.001^{* * *}$ \\
\hline$\omega_{\text {Tue }}$ & -0.00161 & $0.002^{* * *}$ & -0.00131 & $0.001^{* * *}$ & -0.00117 & $0.000^{\star * *}$ \\
\hline$\omega_{W e d}$ & -0.00170 & $0.001^{* * *}$ & -0.00118 & $0.003^{* * *}$ & -0.00104 & $0.002^{* * *}$ \\
\hline$\omega_{\text {Thur }}$ & -0.00151 & $0.005^{\star * *}$ & -0.00127 & $0.002^{* * *}$ & -0.00125 & $0.000^{* * *}$ \\
\hline$\omega_{F r i}$ & 0.00164 & $0.000^{* * *}$ & 0.00138 & $0.000^{* * *}$ & 0.00130 & $0.000^{\star * *}$ \\
\hline$\alpha_{0}$ & 0.00000 & $0.030^{* *}$ & 0.00000 & $0.001^{* * *}$ & 0.00000 & $0.001^{* * *}$ \\
\hline$\alpha_{1}$ & 0.04547 & $0.000^{* * *}$ & 0.05035 & $0.000^{* * *}$ & 0.04965 & $0.000^{* * *}$ \\
\hline$\beta_{1}$ & -0.07825 & 0.503 & -0.28993 & $0.004^{* * *}$ & -0.19508 & $0.090^{* *}$ \\
\hline$\gamma_{1}$ & 0.94625 & $0.000^{* * *}$ & 0.95404 & $0.000^{* * *}$ & 0.95079 & $0.000^{\star * *}$ \\
\hline$\delta$ & 1.66345 & $0.000^{* * *}$ & 1.24743 & $0.000^{* * *}$ & 1.36498 & $0.000^{* * *}$ \\
\hline$v$ & - & - & 4.74212 & $0.000^{* * *}$ & 1.18170 & $0.000^{\star * *}$ \\
\hline
\end{tabular}

In the next stage of the analysis, the effect of the day of the week was verified using the models presented in theoretical part of this paper. The 
seasonality effect was included in the conditional mean equation. At the beginning, the assumption of normality of returns was examined. The results showed that this hypothesis has to be rejected. In the next step, based on the appropriate statistical tests (the information criteria, Jung-Box autocorrelation test and the ARCH effect test), the following models were finally selected for given lags: $\mathrm{AR}(1)-\mathrm{GARCH}(1,1)$ and $\mathrm{AR}(1)-\mathrm{APARCH}(1,1)$. It was also assumed that the rest of the model follow normal (N), t-Student (S) and GED distributions. The stability of model parameters was assessed using the Chow and Nyblom tests. In tables $2-4$, as example, the results obtained for testing the day of the week effect for gold (entire period), palladium (a period of upward trend) and platinum (a period of downward trend) are presented.

Table 3. AR-GARCH and AR-APARCH models - palladium - period of upward trend

\begin{tabular}{|c|c|c|c|c|c|c|}
\hline Parameter & $\mathrm{AR}(1)-\mathrm{GARCH}(1,1)-\mathrm{N}$ & $p$-value & AR(1)-GARCH(1,1)-S & $p$-value & $\mathrm{AR}(1)-\mathrm{GARCH}(1,1)-\mathrm{GED}$ & p-value \\
\hline$\varphi_{0}$ & 0.00151 & $0.037^{* *}$ & 0.00118 & $0.044^{* *}$ & 0.04351 & $0.000^{* * *}$ \\
\hline$\varphi_{1}$ & 0.11368 & $0.000^{* * *}$ & 0.08499 & $0.000^{* * *}$ & 0.00041 & $0.000^{* * *}$ \\
\hline$\omega_{M o n}$ & -0.00228 & $0.028^{* *}$ & -0.00173 & $0.038^{* *}$ & -0.00053 & $0.000^{* * *}$ \\
\hline$\omega_{\text {Tue }}$ & -0.00166 & 0.102 & -0.00103 & 0.210 & -0.00041 & $0.000^{* * *}$ \\
\hline$\omega_{W e d}$ & -0.00128 & 0.196 & -0.00040 & 0.636 & -0.00012 & 0.905 \\
\hline$\omega_{\text {Thur }}$ & -0.00157 & 0.139 & -0.00105 & 0.223 & -0.00041 & $0.000^{* * *}$ \\
\hline$\omega_{F r i}$ & 0.00151 & $0.037^{\star *}$ & 0.00118 & $0.044^{* *}$ & 0.00041 & 0.551 \\
\hline$\alpha_{0}$ & 0.00002 & $0.006^{* * *}$ & 0.00001 & $0.013^{* *}$ & 0.00001 & $0.009^{* * *}$ \\
\hline$\alpha_{1}$ & 0.13384 & $0.000^{* * *}$ & 0.17310 & $0.000^{* * *}$ & 0.15462 & $0.000^{* * *}$ \\
\hline$\beta_{1}$ & 0.84171 & $0.000^{* * *}$ & 0.82803 & $0.000^{* * *}$ & 0.83330 & $0.000^{* * *}$ \\
\hline$v$ & - & - & 4.20127 & $0.000^{* * *}$ & 1.08528 & $0.000^{\star * *}$ \\
\hline Parameter & AR(1)-APARCH(1,1)-N & $p$-value & AR(1)-APARCH(1,1)-S & $p$-value & AR(1)-APARCH(1,1)-GED & $p$-value \\
\hline$\varphi_{0}$ & 0.00156 & $0.056^{*}$ & 0.00122 & 0.162 & 0.00044 & $0.000^{* * *}$ \\
\hline$\varphi_{1}$ & 0.11159 & $0.000^{* * *}$ & 0.08166 & $0.000^{* * *}$ & 0.04126 & $0.000^{* * *}$ \\
\hline$\omega_{M o n}$ & -0.00222 & $0.048^{* *}$ & -0.00173 & 0.112 & -0.00055 & $0.000^{* * *}$ \\
\hline$\omega_{\text {Tue }}$ & -0.00159 & 0.144 & -0.00101 & 0.332 & -0.00044 & $0.000^{\star * *}$ \\
\hline$\omega_{W e d}$ & -0.00124 & 0.263 & -0.00038 & 0.742 & -0.00014 & $0.000^{* * *}$ \\
\hline$\omega_{\text {Thur }}$ & -0.00154 & 0.183 & -0.00100 & 0.406 & -0.00044 & $0.000^{* * *}$ \\
\hline$\omega_{F r i}$ & 0.00156 & $0.045^{\star *}$ & 0.00122 & $0.042^{* *}$ & 0.00044 & $0.000^{* * *}$ \\
\hline$\alpha_{0}$ & 0.00002 & $0.008^{\star \star \star}$ & 0.00002 & $0.015^{\star *}$ & 0.00002 & $0.010^{* *}$ \\
\hline$\alpha_{1}$ & 0.14094 & $0.000^{* * *}$ & 0.17941 & $0.000^{* * *}$ & 0.16495 & $0.000^{\star * *}$ \\
\hline$\beta_{1}$ & -0.05296 & 0.409 & -0.06803 & 0.224 & -0.06944 & 0.150 \\
\hline$\gamma_{1}$ & 0.84864 & $0.000^{* * *}$ & 0.84015 & $0.000^{* * *}$ & 0.84345 & $0.000^{* * *}$ \\
\hline$\delta$ & 1.67146 & $0.000^{* * *}$ & 1.35168 & $0.000^{* * *}$ & 1.38839 & $0.000^{* * *}$ \\
\hline$v$ & - & - & 4.15511 & $0.000^{* * *}$ & 1.08185 & $0.000^{* * *}$ \\
\hline
\end{tabular}

Discussing the results presented in the tables above, it was indicated that for the analyzed metals, the statistically significant effects of the week were mainly observed during the entire period or during the upward trend period. In the case of a downward trend, these results can't be unambiguously confirmed. Similar results were obtained for other metals in the examined subperiods. The values of $\gamma_{1}$ for each model are positive which means that 
negative information has stronger impact than the positive information on the returns volatility of analyzed metals. The figures below present synthetic results obtained for all metals tested for every day of the week. The sign $(+)$ indicates the positive return, while the sign $(-)$-negative respectively. Shaded cells indicate statistically significant returns.

Table 4. AR-GARCH and AR-APARCH models - platinum - period of downward trend

\begin{tabular}{ccccccc}
\hline Parameter & $\mathrm{AR}(1)$-GARCH(1,1)-N & $\mathrm{p}$-value & $\mathrm{AR}(1)$-GARCH(1,1)-S & p-value & $\mathrm{AR}(1)$-GARCH(1,1)-GED & $\mathrm{p}$-value \\
\hline$\varphi_{0}$ & -0.00022 & 0.761 & -0.00030 & 0.663 & -0.00030 & 0.873 \\
$\varphi_{1}$ & 0.07461 & $0.021^{* *}$ & 0.06262 & 0.038 & 0.06995 & $0.023^{* *}$ \\
$\omega_{\text {Mon }}$ & -0.00110 & 0.282 & -0.00078 & 0.431 & -0.00074 & 0.670 \\
$\omega_{\text {Tue }}$ & -0.00016 & 0.869 & -0.00001 & 0.993 & 0.00008 & 0.969 \\
$\omega_{\text {Wed }}$ & -0.00024 & 0.809 & -0.00028 & 0.774 & -0.00024 & 0.935 \\
$\omega_{\text {Thur }}$ & -0.00014 & 0.893 & -0.00010 & 0.919 & -0.00016 & 0.946 \\
$\omega_{\text {Fri }}$ & -0.00022 & 0.761 & -0.00030 & 0.663 & -0.00030 & 0.682 \\
$\alpha_{0}$ & 0.00000 & 0.164 & 0.00000 & 0.142 & 0.00000 & 0.140 \\
$\alpha_{1}$ & 0.03465 & $0.003^{* * *}$ & 0.03374 & $0.001^{* * *}$ & 0.03441 & $0.001^{* * *}$ \\
$\beta_{1}$ & 0.95579 & $0.000^{* * *}$ & 0.95879 & $0.000^{* * *}$ & 0.95664 & $0.000^{* * *}$ \\
$v$ & - & - & 13.18740 & $0.001^{* * *}$ & 1.67895 & $0.000^{* * *}$ \\
\hline Parameter & $\mathrm{AR}(1)-\mathrm{APARCH}(1,1)-\mathrm{N}$ & $\mathrm{p}$-value & $\mathrm{AR}(1)-\mathrm{APARCH}(1,1)-\mathrm{S}$ & $\mathrm{p}$-value & $\mathrm{AR}(1)-\mathrm{APARCH}(1,1)-\mathrm{GED}$ & $\mathrm{p}$-value \\
\hline$\varphi_{0}$ & -0.00044 & 0.489 & -0.00042 & 0.491 & -0.00045 & 0.276 \\
$\varphi_{1}$ & 0.06781 & $0.018^{* *}$ & 0.05963 & $0.051^{*}$ & 0.06531 & $0.040^{* *}$ \\
$\omega_{\text {Mon }}$ & -0.00095 & 0.340 & -0.00069 & 0.420 & -0.00065 & 0.434 \\
$\omega_{\text {Tue }}$ & 0.00001 & 0.989 & 0.00007 & 0.941 & 0.00017 & 0.500 \\
$\omega_{\text {Wed }}$ & 0.00004 & 0.970 & -0.00010 & 0.920 & -0.00002 & 0.985 \\
$\omega_{\text {Thur }}$ & 0.00002 & 0.988 & 0.00000 & 0.997 & -0.00003 & 0.971 \\
$\omega_{\text {Fri }}$ & -0.00044 & 0.561 & -0.00042 & 0.535 & -0.00045 & 0.522 \\
$\alpha_{0}$ & 0.00000 & 0.256 & 0.00000 & 0.275 & 0.00000 & 0.262 \\
$\alpha_{1}$ & 0.02989 & $0.018^{* *}$ & 0.03046 & $0.003^{* * *}$ & 0.03036 & $0.013^{* *}$ \\
$\beta_{1}$ & 0.41536 & 0.391 & 0.28854 & 0.636 & 0.37204 & 0.489 \\
$\gamma_{1}$ & 0.96999 & $0.000^{* * *}$ & 0.96847 & $0.000^{* * *}$ & 0.96935 & $0.000^{* * *}$ \\
$\delta$ & 1.25298 & 0.166 & 1.50355 & 0.434 & 1.30223 & 0.280 \\
$v$ & - & - & 14.20030 & $0.002^{* * *}$ & 1.70171 & $0.000^{* * *}$ \\
\hline & & & & &.
\end{tabular}

The results confirm the existence of day of the week effect, mainly in the case of gold and palladium in the whole period and in the period of upward trend. Statistically significant positive returns were observed on Fridays, while during the other days the returns were negative. Different results were obtained for the period of downward trend. There were statistically significant negative returns on Tuesdays and Wednesdays. Taking into account the models used, the statistical significance of the day of the week effect was primarily observed for models with the distribution of residuals described by the t-Student or GED distribution. It may be the result of clustering in variance and existence of outliers. The selection of final model depends on the values of information criteria given by the formulas (14)-(16). The results are below. 
Table 5. Day of the week effect - statistically significant results - entire period

\begin{tabular}{ccccccc}
\hline SILVER & AR-GARCH-N AR-GARCH-S AR-GARCH-GED AR-APARCH-N AR-APARCH-S AR-APARCH-GED \\
\hline MONDAY & - & - & - & - & - & - \\
TUESDAY & - & - & - & - & - & - \\
WEDNESDAY & - & - & - & - & - & - \\
THURSDAY & - & - & + & - & - & + \\
FRIDAY & + & + & + & + & + & + \\
\hline GOLD & AR-GARCH-N AR-GARCH-S AR-GARCH-GED AR-APARCH-N AR-APARCH-S AR-APARCH-GED \\
\hline MONDAY & - & - & - & - & - & - \\
TUESDAY & - & - & - & - & - & - \\
WEDNESDAY & - & - & - & - & - & - \\
THURSDAY & - & - & - & - & - & - \\
FRIDAY & + & + & + & + & + & + \\
\hline PALLADIUM & AR-GARCH-N AR-GARCH-S AR-GARCH-GED AR-APARCH-N AR-APARCH-S AR-APARCH-GED \\
\hline MONDAY & - & - & - & - & - & - \\
TUESDAY & - & - & - & - & - & - \\
WEDNESDAY & - & - & - & - & - & - \\
THURSDAY & - & - & - & - & - & - \\
FRIDAY & + & + & + & + & + \\
\hline PLATINUM & AR-GARCH-N AR-GARCH-S AR-GARCH-GED AR-APARCH-N AR-APARCH-S AR-APARCH-GED \\
\hline MONDAY & - & - & - & - & - & - \\
TUESDAY & - & - & - & - & - & - \\
WEDNESDAY & - & - & + & - & + & + \\
THURSDAY & - & - & - & - & - & - \\
FRIDAY & + & + & + & + & + \\
\hline
\end{tabular}

Table 6. Day of the week effect - statistically significant results - period of upward trend

\begin{tabular}{ccccccc}
\hline SILVER & AR-GARCH-N & AR-GARCH-S AR-GARCH-GED AR-APARCH-N AR-APARCH-S AR-APARCH-GED \\
\hline MONDAY & - & - & - & - & - & - \\
TUESDAY & - & - & - & - & - & - \\
WEDNESDAY & - & - & - & - & - & - \\
THURSDAY & - & - & - & - & - & - \\
FRIDAY & + & + & + & + & + & + \\
\hline GOLD & AR-GARCH-N & AR-GARCH-S AR-GARCH-GED AR-APARCH-N AR-APARCH-S AR-APARCH-GED \\
\hline MONDAY & - & - & - & - & - & - \\
TUESDAY & - & - & - & - & - & - \\
WEDNESDAY & - & - & - & - & - & - \\
THURSDAY & - & - & - & - & - & - \\
FRIDAY & + & + & + & + & + & + \\
\hline PALLADIUM & AR-GARCH-N AR-GARCH-S AR-GARCH-GED AR-APARCH-N AR-APARCH-S AR-APARCH-GED \\
\hline MONDAY & - & - & - & - & - & - \\
TUESDAY & - & - & - & - & - & - \\
WEDNESDAY & - & - & - & - & - & - \\
THURSDAY & - & - & - & - & - & - \\
FRIDAY & + & + & + & + & + & + \\
\hline PLATINUM & AR-GARCH-N AR-GARCH-S AR-GARCH-GED AR-APARCH-N AR-APARCH-S AR-APARCH-GED & + & + \\
MONDAY & - & - & + & - & + & - \\
TUESDAY & - & - & - & - & - & + \\
WEDNESDAY & - & + & + & - & + & + \\
THURSDAY & - & - & - & - & + & + \\
FRIDAY & + & + & + & + & + & + \\
\hline
\end{tabular}

Dynamic Econometric Models 18 (2018) 81-97 
Table 7. Day of the week effect - statistically significant results - period of downward trend

\begin{tabular}{|c|c|c|c|c|c|c|}
\hline SILVER & AR-GARCH-N & AR-GARCH-S & AR-GARCH-GED & AR-APARCH-N & AR-APARCH-S & AR-APARCH-GED \\
\hline MONDAY & - & - & + & - & - & + \\
\hline TUESDAY & - & - & - & - & - & - \\
\hline WEDNESDAY & - & - & - & + & - & - \\
\hline THURSDAY & - & + & + & - & + & + \\
\hline FRIDAY & - & - & - & + & - & - \\
\hline GOLD & AR-GARCH-N & AR-GARCH-S & AR-GARCH-GED & AR-APARCH-N & AR-APARCH-S & AR-APARCH-GED \\
\hline MONDAY & - & - & - & - & - & - \\
\hline TUESDAY & - & - & - & - & - & - \\
\hline WEDNESDAY & - & - & - & - & - & - \\
\hline THURSDAY & - & - & - & - & - & - \\
\hline FRIDAY & + & + & + & + & + & + \\
\hline PALLADIUM & AR-GARCH-N & AR-GARCH-S & AR-GARCH-GED & AR-APARCH-N & AR-APARCH-S & AR-APARCH-GED \\
\hline MONDAY & - & - & - & - & - & - \\
\hline TUESDAY & - & - & - & - & - & - \\
\hline WEDNESDAY & - & - & - & - & - & - \\
\hline THURSDAY & - & - & - & - & + & + \\
\hline FRIDAY & + & + & + & + & + & + \\
\hline PLATINUM & AR-GARCH-N & AR-GARCH-S & AR-GARCH-GED & AR-APARCH-N & AR-APARCH-S & AR-APARCH-GED \\
\hline MONDAY & - & - & - & - & - & - \\
\hline TUESDAY & - & - & + & + & + & + \\
\hline WEDNESDAY & - & - & - & + & - & - \\
\hline THURSDAY & - & - & - & + & + & - \\
\hline FRIDAY & - & - & - & - & - & - \\
\hline
\end{tabular}

Considering the entire period we noticed that for gold and silver, the best fitted model was the AR-APARCH model with conditional t-Student distribution of residuals. For palladium and platinum information criteria give different assessments, however, these are still models with residuals described by conditional t-Student distribution. Similar results were obtained for gold and silver during the upward trend. In the case of palladium, the AR-GARCH model with the GED distribution for residuals was proposed, while for platinum the AR-APARCH model with t-Student distribution. The last subperiod represents the downward trend. The results suggest different models: for silver, AR-GARCH model with GED distribution for residuals, AR-GARCH model for gold with residuals described by t-Student distribution, ARAPARCH model for palladium with t-Student distribution for residuals, and finally AR-GARCH model for platinum with t-Student distribution for residuals as well. We didn't observe any model with conditional normal distribution for residuals. In figure 3 the AR(1)-APARCH(1, 1)-S model for gold and silver is presented (entire period). 
Table 8. Information criteria for estimated models

\begin{tabular}{|c|c|c|c|c|c|c|c|c|c|c|}
\hline \multirow[t]{2}{*}{ METAL } & \multirow[t]{2}{*}{ MODEL } & \multicolumn{3}{|c|}{ ENTIRE PERIOD } & \multicolumn{3}{|c|}{$\begin{array}{c}\text { PERIOD OF UPWARD } \\
\text { TREND }\end{array}$} & \multicolumn{3}{|c|}{$\begin{array}{l}\text { PERIOD OF DOWNWARD } \\
\text { TREND } \\
\end{array}$} \\
\hline & & $\mathrm{AIC}$ & $\mathrm{BIC}$ & $\mathrm{HQC}$ & $\mathrm{AIC}$ & $\mathrm{BIC}$ & $\mathrm{HQC}$ & $\mathrm{AIC}$ & $\mathrm{BIC}$ & $\mathrm{HQC}$ \\
\hline \multirow{6}{*}{ SILVER } & AR-GARCH-N & -23385 & -23327 & -23365 & -16079 & -16025 & -16060 & -7312 & -7265 & -7294 \\
\hline & AR-GARCH-S & -23843 & -23779 & -23820 & -16320 & -16260 & -16299 & -7535 & -7483 & -7515 \\
\hline & AR-GARCH-GED & -23829 & -23765 & -23807 & -16301 & -16240 & -16279 & -7542 & -7490 & -7522 \\
\hline & AR-APARCH-N & -23400 & -23330 & -23375 & -16119 & -16053 & -16095 & -7310 & -7253 & -7289 \\
\hline & AR-APARCH-S & -23873 & -23797 & -23846 & -16352 & -16280 & -16326 & -7531 & -7468 & -7508 \\
\hline & AR-APARCH-GED & -23850 & -23774 & -23823 & -16330 & -16258 & -16304 & -7539 & -7476 & -7516 \\
\hline \multirow{6}{*}{ GOLD } & AR-GARCH-N & -27574 & -27517 & -27554 & -18875 & -18821 & -18856 & -8694 & -8647 & -8677 \\
\hline & AR-GARCH-S & -27987 & -27923 & -27964 & -19115 & -19055 & -19094 & -8873 & -8820 & -8853 \\
\hline & AR-GARCH-GED & -27975 & -27911 & -27952 & -19112 & -19052 & -19091 & -8864 & -8812 & -8844 \\
\hline & AR-APARCH-N & -27575 & -27505 & -27550 & -18908 & -18842 & -18884 & -8707 & -8649 & -8685 \\
\hline & AR-APARCH-S & -28005 & -27928 & -27977 & -19139 & -19067 & -19113 & -8876 & -8813 & -8852 \\
\hline & AR-APARCH-GED & -27983 & -27907 & -27956 & -19134 & -19062 & -19108 & -8866 & -8803 & -8842 \\
\hline \multirow{6}{*}{ PALLADIUM } & AR-GARCH-N & -22449 & -22391 & -22429 & -14987 & -14933 & -14968 & -7468 & -7421 & -7450 \\
\hline & -GARCH-S & -22755 & -22692 & -22 & -15275 & -15215 & -15253 & -7491 & -7439 & -7472 \\
\hline & AR-GARCH-GED & -22753 & -22689 & -22731 & -15294 & -15234 & -15273 & -7485 & -7433 & -7466 \\
\hline & AR-APARCH-N & -22447 & -22376 & -224 & -14 & -14922 & -14964 & -7484 & -7427 & -7463 \\
\hline & AR-APARCH-S & -22758 & -22682 & -22731 & -15281 & -15209 & -15255 & -7508 & -7445 & -7484 \\
\hline & AR-APARCH-GED & -22754 & -22677 & -22727 & -15299 & -15226 & -15273 & -7492 & -7439 & -7476 \\
\hline \multirow{6}{*}{ PLATINUM } & AR-GARCH-N & -25876 & -25819 & -25856 & -17649 & -17595 & -17629 & -8246 & -8199 & -8228 \\
\hline & AR-GARCH-S & -26065 & -26001 & -26042 & -17833 & -17772 & -17811 & -8258 & -8205 & -8238 \\
\hline & AR-GARCH-GED & -26046 & -25982 & -26024 & -17822 & -17762 & -17801 & -8254 & -8202 & -8235 \\
\hline & AR-APARCH-N & -25889 & -25819 & -25864 & -17671 & -17604 & -17647 & -8247 & -8190 & -8226 \\
\hline & AR-APARCH-S & -26075 & -25998 & -26048 & -17848 & -17776 & -17822 & -8256 & -8194 & -8233 \\
\hline & AR-APARCH-GED & -26056 & -25979 & -26029 & -17838 & -17766 & -17812 & -8254 & -8191 & -8231 \\
\hline
\end{tabular}
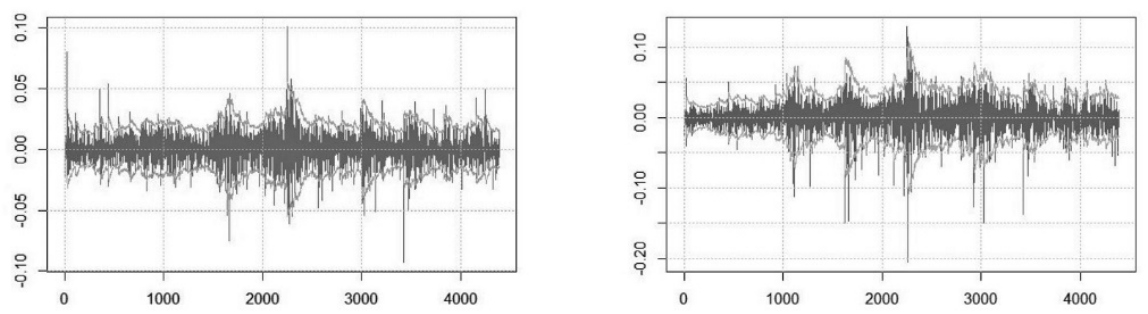

Figure 3. AR(1)-APARCH(1,1)-S model for gold (left) and silver (right) - entire period

In conclusion, it can be said that the models describing conditional mean and conditional variance should be described by heavy-tails distributions for residuals. It is also reasonable to use models that take into account the asymmetry observed in a data. 


\section{Conclusions}

The paper attempts to describe calendar anomalies in the case of precious metals market. That kind of anomalies deny the problem of market efficiency and their detection allows to obtain additional information about volatility of financial assets. The research area of precious metals is part of commodity market (metals market), an alternative to the capital one. Diversification of the structure of the financial portfolio with components from different markets allows to protect against unpredictable events that may affect the broadly understood economic situation.

The entire research period was divided into two sub-periods: period of upward trend and period of downward trend. An attempt was to verify whether general economic trends affect the occurrence of the day of the week effect. As a time series models the class of AR-APARCH models with conditional residual distributions (normal, t-Student and GED) were proposed. The seasonality effect was included in the conditional mean equation. The selection of models was made on the basis of appropriate diagnostic tests. The results show that in the entire period the returns on Fridays (positive) were significantly different from these obtained for the other days of the week. Similar results were observed during the period of upward trend. Negative results for individual days of the week were observed during the period of downward trend.

As we can see, the results are not unambiguous. In summary, the day of the week effect was observed for the volatility of gold returns in the entire period and in the period of upward trend (positive returns on Fridays, negative for the other days). The day of the week effect was also observed for the volatility of the palladium returns in the entire period and in the period of upward trend (positive returns on Fridays, negative on Mondays, Tuesdays and Thursdays). Moreover, it was pointed out that the AR-APARCH models should be used when taking into account the heavy-tail distributions for describing model residuals (mainly the Student's t-distribution).

\section{References}

Aksoy, M. (2013), Day of The Week Anomaly for Istanbul Gold Exchange: Gold and Silver Data, Muhasebe Finansman Dergisi, Ocak 2013, 149-164.

Arora, S., Garg, N. (2013), Day of the Week Effect on Gold Returns, DOI: http://dx.doi.org/10.2139/ssrn.2229290.

Bachelier L. (1900), Théorie de la spéculation, Annales Scientifiques de l'École Normale Supérieure, 3(17), 21-86.

Bollerslev, T. (1986), Generalised autoregressive conditional heteroskedasticity, Journal of Econometrics, 31, 307-327, DOI: https://doi.org/10.1016/0304-4076(86)90063-1. 
Ding, Z., Granger, C. W. J., Engle, R. F. (1993), A long memory property of stock market returns and a new model, Journal of Empirical Finance, 1, 83-106, DOI: https://doi.org/10.1016/0927-5398(93)90006-D.

Draper, P., Faff R.W., Hillier, D. (2006), Do Precious Metals Shine? An Investment Perspective, Financial Analysts Journal, 62(2), 98-106, DOI: https://doi.org/10.2469/faj.v62.n2.4085.

Fama, E. (1970), Efficient Capital Markets: A Review of Theory and Empirical Work, Journal of Finance, 25(2), 383-417, DOI: https://doi.org/10.2307/2325486.JSTOR 2325486.

Fiszeder, P., Kożuchowska, J. (2013), Testowanie występowania wybranych anomalii kalendarzowych na GPW w Warszawie, [in:] A. S. Barczak, P. Tworek, (ed.), „Zastosowanie metod ilościowych w zarządzaniu ryzykiem w działalności inwestycyjnej, Polskie Towarzystwo Ekonomiczne Oddział Katowice”, Wydawnictwo Uniwersytetu Ekonomicznego w Katowicach, Katowice, 217-229.

French, K. (1980), Stock returns and weekend effect, Journal of Financial Economics, 8, 55-69, DOI: https://doi.org/10.1016/0304-405X(80)90021-5.

Ganczarek-Gamrot, A. (2013), Metody stochastyczne w badaniach porównawczych wybranych rynków energii elektrycznej, Wydawnictwo Uniwersytetu Ekonomicznego w Katowicach, Katowice

Jaffe, J., Westerfield, R. (1985), The Week-End Effect in Common Stock Returns: The International Evidence, The Journal of Finance, 40(2), 433-454, DOI: https://doi.org/10.1111/j.1540-6261.1985.tb04966.x.

Karanasos, M., Kim, J. (2006), A re-examination of the asymmetric power ARCH model, Journal of Empirical Finance, 13, 113-128, DOI: https://doi.org/10.1016/j.jempfin.2005.05.002.

Lakonishok, J., Smidt, S., (1988), Are Seasonal Anomalies Real? A Ninety-Year Perspective, Review of Financial Studies, 1(4), 403-425, DOI: https://doi.org/10.1093/rfs/1.4.403.

Landmesser, J., (2006), Efekt dnia tygodnia na Giełdzie Papierów Wartościowych w Warszawie, Zeszyty Naukowe Ekonomika i Organizacja Gospodarki Żywnościowej, 60, 187-196.

Ma, C. (1986), A further investigation of the day-of-the-week effect in the gold market, Journal of Futures Markets, 6, 409-419, DOI: https://doi.org/10.1002/fut.3990060306.

Piontek, K. (2002), Pomiar ryzyka metodą VaR a modele AR-GARCH ze składnikiem losowym o warunkowym rozkładzie z "grubymi ogonami", Materiały Konferencyjne Uniwersytetu Szczecińskiego, Część II, 467-484.

Raj, K. Kohli (2012), Day-of-the-week effect and January effect examined in gold and silver metals Insurance Markets and Companies, 3(2), 21-26.

Szyszka, A. (1999), Efektywność rynku a anomalie w rozkładzie stóp zwrotu w czasie, Nasz Rynek Kapitalowy, 108, 55-61.

Tsay, R., 2005, Analysis of financial time series, Chicago, Wiley \& Sons.

Witkowska, D., Kompa, K. (2007), Analiza własności stóp zwrotu akcji wybranych spółek, Zeszyty Naukowe Uniwersytetu Szczecińskiego. Finanse, Rynki Finansowe, Ubezpieczenia, 6, 255-266.

\section{Testowanie efektu dnia tygodnia na rynku metali szlachetnych}

Z a r y s t r e ś c i. Efektywność rynku zakłada, że ceny aktywów powinny cechować się losowością i nieprzewidywalnością tak, aby potencjalni uczestnicy rynku nie byli wstanie generować ponadprzeciętnych zysków. Oznacza to, że w szeregach czasowych nie powinno występować zjawisko sezonowości, które jednoznacznie wyznacza pewien wzorzec zachowań 
aktywów finansowych. W referacie podjęto próbę weryfikacji efektu dnia tygodnia na rynku metali szlachetnych. Wybór obszaru badawczego nie jest akcydentalny. Metale szlachetne stanowią alternatywę dla klasycznych inwestycji kapitałowych, zwłaszcza w przypadku kryzysów finansowych i gospodarczych. Ponadto literatura przedmiotu wykazuje lukę w obszarze analiz dynamiki na rynkach towarowych w porównaniu z aktywami rynku kapitałowego. Wyniki nie są jednoznaczne. Efekt dnia tygodnia zaobserwowano przede wszystkim dla stóp zwrotu złota i palladu (cały okres i okres wzrostu) oraz sporadycznie dla stóp zwrotu srebra (okres trendu spadkowego). Badanie wykazało, że w kontekście kryteriów informacyjnych należy stosować modele AR-APARCH z gruboogonowymi rozkładami prawdopodobieństwa dla reszt

S łow a kluczowe: efekt dnia tygodnia; metale szlachetne; model APARCH; model GARCH; szeregi czasowe. 